\title{
Cuando el misterio insiste: The construction of authority in Dominican Vodou ${ }^{1}$
}

\author{
Yvonne SCHAFFLER \& Bernd BRABEC DE MORI
}

\section{Abstracts}

The form of spirit possession performed by practitioners who are readily initiated into Dominican Vodou requires them to be excellent (inter-)actors, dancers, and poets. The article focuses on the ritual practice of spirit possession in the Southwest of the Dominican Republic with emphasis on the question as to what constitutes effectiveness of spirit performance and how it is produced. The authors do so by drawing upon videographic data created for methodological purposes within the context of a larger project on the "Modes and Function of Spirit Possession", funded by the Austrian Science Fund, and archived at the Phonogrammarchiv of the Austrian Academy of Sciences, as well as on interviews with performers. A specific focus is devoted to the construction of authority, that is by what means a spirit possession episode is recognised by peers as truly mandatory in the sense of the messages it conveys. Among factors that are directly linked to successful ritual performance are a careful orchestration and execution of the event, a display of deep emotional immersion into the spirit character and a correlation with some minimum standardised forms. However, we found that authority is also constructed through aspects outside the ritual framework such as a medium's socio-economic status and moral lifestyle, as well as her standing in good terms with peers. Only on top of that can the performance by itself condense all directly linked factors into an authoritative manifestation of a spirit in the human world.

Vollständig initiierte Praktizierende des Dominikanischen Vodou benötigen für ihre Performance von Besessenheit exzellente schauspielerische, tänzerische, und dichterische Fähigkeiten. Dieser Artikel befasst sich mit der rituellen Praxis von Geistbesessenheit im Südwesten der Dominikanischen Republik, wobei wir uns der Frage widmen, was effektive Performance ausmacht und wie sie produziert wird. Dabei beziehen wir uns auf Video- und Interviewdaten, die zu methodischen Zwecken im Rahmen eines durch den Österreichischen Forschungsfonds finanzierten größeren Projekts zu "Modi und Funktion von Geistbesessenheit" hergestellt und im Phonogrammarchiv der Österreichischen Akademie der Wissenschaften archiviert wurden. Besonderes Augenmerk liegt auf der Konstruktion von Autorität und der Frage, mit welchen Mitteln erreicht wird, dass die während der Besessenheit transportierten Botschaften von den anderen

1 Yvonne Schaffler would like to thank the Austrian Science Fund (FWF: T525-G17) for funding her research since 2011. Both authors also thank the Phonogrammarchiv for archiving our video and audio recordings since 2001, for providing recording equipment and technical advice, and for inviting us to contribute to the current issue of the International Forum on Audio-Visual Research. 
Ritualteilnehmer/inne/n ernst genommen werden. Unter den Faktoren, die für eine erfolgreiche Performanz unmittelbar bestimmend sind, finden sich eine sorgfältige Orchestrierung und Leitung des Events, die Darstellung tief empfundener Gefühle sowie ein Minimum an Übereinstimmung mit standardisierten Darstellungsformen. Allerdings wird Autorität auch durch außerhalb des rituellen Rahmens liegende Aspekte produziert, darunter der sozio-ökonomische Status und Lebensstil des Mediums sowie seine/ihre freundschaftliche Beziehungen zu Kolleg/inn/en. Nur auf Letztere aufbauend gelingt es dem Medium, alle unmittelbar mit der Performanz verbundenen Faktoren so zu bündeln, dass durch Besessenheit Autorität entsteht.

\section{Keywords}

Spirit possession, ritual practice, Dominican Vodou, construction of authority, videography Besessenheit, rituelle Praxis, Dominikanisches Vodou, Konstruktion von Autorität, Videographie

\section{Introduction}

Every case of possession has its theatrical side, as shown in the matter of disguises. The room[s] of the sanctuary are not unlike the wings of a theatre where the possessed find the necessary accessories. (Métraux 1955: 24)

The present article focuses on spirit possession in the Dominican Republic within the framework of Vodou, whose rituals encompass dramatic elements, suggesting a sacred form of theatre (Saint-Lot 2003). The core of our observations constitute the aesthetics and dramatic enactments of possessed interaction, as well as the interconnected question what constitutes an effective and authoritative spirit performance. This article builds on previous work (Schaffler \& Brabec de Mori 2015), where some of the most salient features of spirit possession in the Dominican Republic were highlighted by describing the setting, choreography, and protagonists of public celebrations. We identified factors that shape possession trance behaviour, like timing, experience, or skilfulness. Moreover, we introduced a central metaphor of Vodou called "spiritual force" (fuerza espiritual), and we showed how ritual practices revolve around this concept. In the section on the ethnographic background, we proceed in the present paper by further exploring the concept of "spiritual force" alongside with other root metaphors such as sacred "knowledge" (conciencia) and "heating up" (calentar). In addition to this fundamentally emic conceptualisations, we will also focus on items and processes that, from an etic perspective, constitute an effective performance of possession that allows the possessing spirit to acquire the authority for others to follow. Thereby we draw on the work by Schieffelin 
(1996), who suggested analysing mediumistic interaction by relating to issues such as emergence, form, agenda, means, embodiment, and performance strategy (ibid.: 64), and following what Halloy \& Naumescu (2012: $160)$ described as a "turn towards performance and embodiment in studies of spirit possession". This discourse focuses on the body of the possessed as a means for expressing shared values and beliefs, and on embodied experience (e.g. Halloy 2013; Pierini 2016b; Rouget 1985; Sax \& Weinhold 2010; Seligman 2010). With our attempt to understand which skills are mandatory for a possessed individual in order to being accepted in her role as a spiritual authority and healer, our article also contributes to the current debate on possession expertise (e.g. Espirito Santo 2012, 2015; Halloy 2012, 2013; Pierini 2016a).

\section{Aims and methods}

As our main interest lies in the bodily expression, interaction and affection of the possessed, we approach this aim by analysing possession through videographic material. Videography allows for real-time sequential and fine-grained multimodal record on the one hand, and on the other, to closely observe the temporal and sequential structure, including the nonverbal cues of events (Jewitt 2012; Knoblauch et al. 2006: 19). The footage was collected between 2009 and 2013 by Schaffler, during four periods of ethnographic fieldwork totalling up to twelve months. The main part of fieldwork was conducted in the context of a project on "Modes and Function of Spirit Possession". Further methods that laid way to this article comprise participant observation, narrative interviews focusing on biography and spiritual development, and problem-centred interviews including a range of questions regarding religious practice. The video footage and part of the interviews were archived at the Phonogrammarchiv of the Austrian Academy of Sciences. All data were collected in the Dominican Southwest, locally referred to as el Sur. Emic and some etic categories that emerged from the written data were organised using the software atlas.ti following the principle of Grounded Theory.

In order to understand the structure and character of successful possession and the relations between performer and audience, we will foreground an ethnographic example of a female practitioner of Vodou who we identify here as Ana. ${ }^{2}$ She is a respected and renowned member of the

2 The name, along with those of other practitioners mentioned in the course of our argument, was changed in accordance with the Helsinki declaration of ethics in medicine. Our analysis also makes use of some further examples including footage and written data, which are, however, not presented in detail. 
vodouist community and functions as a priestess and healer. We chose her as a representative case because we perceived her spirit performance as utterly convincing. Likewise, her peers described her as a person disposing of "much spiritual force", and thus she is ascribed the ability to manifest the spirits in a particularly "beautiful" and "firm" style. Through a microanalytical investigation of selected videographic scenes we will shed some light on the nature of the relation between Ana as a "performer" and her "audience", in order to determine how she creates the spirits' presence and sustains it by performative means.

We acknowledge that the idea of relationships in a performance may seem unsettling to the reader, because in the Euro-American (Aristotelian) tradition, theatre carries the notion of two divided realities: the world of the spectators, which is "real", and the realm of the performers, which is not (Schieffelin 1997: 200-204). We would thus like to point out that we neither think in terms of an ontological bifurcation between the performer and the audience-suffice that this has been challenged by participatory forms of contemporary experimental theatre-nor do we understand acting as a form of inauthenticity. Although, in contrast to acting, everyday behaviour does not follow a certain intention or "plot", it is not necessarily more "authentic" or "truthful", as it often consists of a series of automatic and semi-conscious behaviours, thoughts and experiences, which frequently distort or twist what happens. We might also speak of social roles, or, in terms of psychodynamic theory, of defence mechanisms (Cardeña \& Beard 1999: 103f.). In this vein, both "acting" and social life in general, to a degree, are a matter of performative illusion, and at times, of more or less strategic manipulation (Goffman 2003 [1959]). We want to stress here that vodouists do have a conception of "fake" possession and regard "true" possession as the opposite of deception and manipulation: namely the presence of spirits who perform themselves. We will show in later sections of this article that vodouists relate the quality of possession to the ability of attracting and handling "spiritual force". Therefore, our analysis must be understood as combining emic understandings and explanations with etic observations and analytical tools that also make use of some fundamentally Western assumptions about performativity. 


\section{Ethnographic background}

Spirit possession is the most characteristic and common observable element in Vodou, a religious practice found in both the Haitian and the Dominican parts of the island of Hispaniola. The Dominican Republic provides the scene for the phenomena to be discussed in the following. The ritual practice of Vodou emerged from Western and Central African religions that have been secretly handed down by slaves, while Roman Catholicism was forced upon them during colonial times (Deive 1996; Métraux 1998). Ever since, Catholicism and Vodou have not been mutually exclusive, and from the perspective of Vodou participation, it is not required that other religious affiliations be abandoned (Desmangles 1992: 47). Vodouists refer to themselves as Catholic, while at the same time admitting to "serve the mysteries" (in the Dominican Republic: servir a los misterios, that is to "serve the spirits/saints"). An important difference between the two varieties is that the Dominican Vodou is more eclectic, less structured, but more influenced by European Christian and kardecistic elements (Davis 1987). Moreover, Dominican Vodou (Vodú or in emic terms: La Veintiuna División) is but one praxis within the wider framework of Dominican folk religion or, as Davis (2007b) put it: Dominican folk Catholicism. Because of the often hostile attitude from the Pentecostal churches, Dominican mediums often hide their spiritual practice from the public or tend to emphasise that they "work" (manipulate) above all Saints and Angels in favour of good deed and healing. Haitian magic and spirits, on the other hand, are imbued with a mystique of particularly strong but also dangerous spiritual power, ${ }^{3}$ and Haitian immigrants, with whom Dominicans live in constant ethnic tension, are put under a general suspicion of harnessing dark powers for black magic (Schaffler 2009: 328-342).

During ritual, possessed humans are expected to utter the possessing spirit's characteristic voice, ${ }^{4}$ and to exhibit postures, gestures and complexes of action typical for the specific spirit while being unaware of what their body does, because it becomes the spirit's channel of expression. As the misterio spirits take possession, they are recognised and addressed with their second or "real" names, for example Belié Belcan for the Archangel Michael, Anaísa for Saint Anne, or Candelo Sedifé for Saint Charles (San Carlos Borromeo). In addition to these morally immaculate "white"

3 In ritual specialty stores, for example, one can find containers of various products labeled "Haitian" (Landies 2009: 220; Schaffler 2009: 333f.).

4 Voice masking is an important strategy for indicating and embodying the presence of a spirit in the human world; see for example Brabec de Mori \& Seeger (2013), or Brabec de Mori (in print). 
spirits, vodouists assume that there are 20 more groups (in total: las 21 divisiones) of spirits, among them the so-called Guedes whose activities are confined to the world of the dead (division negra), spirits associated with water (división india), as well as the aggressive and subversive petró spirits (división petró) (Davis 2007b: 83). The latter group of spirits is associated with Haiti and black magic, and few Dominicans voluntarily serve them. However, even Saints may, when being angry, "accidentally" manifest in a petró-aspect, thus engaging in violent and forceful behaviour (Schaffler 2009: 62-64). Female spirits express their concerns gently, and their presence is more subtle and easier in movements. Male spirits tend to be enacted in a more energetic way, they appear stronger and even aggressive in nature; their presence is more visible in the actions of the possessed. As soon as the possessed person-or the possessing spirit, respectively-shifts her attention towards other ritual participants, her symbolic action gives way to a more improvisational interaction. This often involves comments about the clients' private situation, predictions of future events, as well as admonitions or blessings (Schaffler 2009: 141-159). After possession, the returning "Horse" ${ }^{5}$ often reports amnesia for the entire period of trance (Bourguignon 1976; Davis 1987; Deren 1953; Métraux 1998). ${ }^{6}$ Despite the connection of some cases to suffering-as individuals are unable to control the moment and quality of possession (see Schaffler 2017) -, possession is most often a source for increased autonomy, social attention, power, status, material benefits, etc. (Davis 1987; Schaffler et al. 2016). In our analysis, we focus on the beneficial type of spirit manifestation carried out by readily initiated and experienced individuals.

\section{Acquiring the means for performing well}

In comparison with the Bahian Candomble or Cuban Santería, formality in training among Dominican vodouists is minimal (Davis 2007b: 79). However, we would like to stress that only with time, individuals approach perfection in performing spirit behaviour. Ana, whom we chose for our case study, started her career as servant of the spirits at an early age. She told the first author that

I was born with teeth; with four front and two back teeth, which fell out when I was seven years old. [...] So, when I was seven years old, I started to

5 The priests, or specialists in spirit invocation are locally called caballos (Spanish for "horse"), because they seem to be "mounted" by the spirits.

6 See, however, Halperin (1995). 
baptise myself with water. I threw it over my head, on the nape of my neck, and on the front door of the house where I used to live. I began to tell the future. I told the people 'look, you have this' or 'that thing is going to happen to you' or 'that person is going to die.' I also predicted plenty of numbers for the national lottery, and the house of my father was built thanks to the numbers I gave them. I went on to predict numbers and people started to come and visit me and I keep on predicting things until today. And from the age of twelve years on I developed misterios. The patron of my head is the Archangel Michael. ${ }^{7}$

Like many of her peers, Ana emphasised the vocational character of her intuitive knowledge, while at this point ignoring any formal aspects of her initiation (but she mentioned those in later interviews). From an emic viewpoint, "knowledge" (conciencia) is primarily transmitted by the spirits as they send messages to their Horses via dreams and visions. However, the "education of attention and emotion, embodied participation and imaginative explorations" that underlies the initiatory process (Halloy \& Naumescu 2012: 162) is not only achieved through "vocation" or formal training. It has to be developed by means of constant participation in rituals. In this vein, vodouists agree that mediums receive their capacity to manage and increase their innate capability of commanding "spiritual force" (fuerza espiritual) by organising and visiting celebrations and through pilgrimages to sacred sites. According to the emic perspective, the quality of possession is determined by the right amount of "spiritual force" pervading an individual's body. Gestures, postures and movements have to correspond with attributes of the manifesting spirit. Vodouists describe the visible aspect of spiritual force (fuerza espiritual) as "firmness" (firmeza); a tensile and dynamic strength characterising posture, gesture and movement (Schaffler \& Brabec de Mori 2015: 110f.). If a medium is sufficiently prepared (preparado) for the reception of spirits, her spiritual power can forcefully break through her everyday behaviour, resulting in a kind of possession that vodouists would describe as "firm" and "beautiful". Weak spiritual animation, on the other hand, engenders possession with merely undetermined movements. If the animating principle spontaneously leaves the medium, the human body may collapse like an empty sack. If the entering force exceeds the medium's capacity of handling it-for example in the case of spiritual punishment (castigo)-the resulting possession episode may take on a violent character, with the Horse rolling on the floor or hurting herself (Schaffler 2017; Schaffler \& Brabec 
de Mori 2015; Schaffler et al. 2016). To vodouists, "skilfulness" in possession translates into the ability of attracting, receiving and handling spiritual force so that the manifesting spirit (a specific emanation of the force) may use the human body as a means of expression. The process of mediumistic development is a complex path through which mediums learn how to control their sensitivity and exposure to such spiritual powers. On the one hand, they do so by observing and listening to more experienced peers who function, more or less informally, as their mentors. Moreover, during celebrations in honour of the spirits, novices and experienced mediums dance together while in the state of possession. Here, the experienced medium directs and corrects the novice to move according to the aesthetic standards of Vodou. The teaching spirit may pass on, for example, details of a ritual salutation unknown to the possessed novice, or transmit some of its own spiritual force via eye contact. Since the essential ritual "knowledge" (conciencia) is transmitted through a spirit during possession, the idea that becoming a medium involves some kind of formal training does not preclude the commonly shared cultural narrative. According to this narrative, possession is a sacred ability transmitted by the spirits only to those who are chosen. In other situations of knowledge transmission, the "teacher" may not be possessed, but $\mathrm{s} /$ he serves as a ritual assistant (plaza). In such a case, the experienced medium handles ritual paraphernalia like a hand bell used for calling the spirit, and applies and manages prayer, perfume, food and drinks just in a way that encourages the novice to let him-/herself fall deeply into the spirit role (Schaffler 2017; unpublished data and videographic observation ${ }^{8}$ ).

\section{"Heating up" a public celebration}

The idea of "spiritual force" is not only connected to the ritual practice of possession but also to public relations and the acquisition of money. Public, communal celebrations (fiestas de misterios, maní) are either held in honour of specific spirits on their calendrical celebration day, or they are offered in the aftermath of successful healing, in gratitude or in payment of a vow, or they may be celebrated on the occasion of the initiation of a new member of the vodouist community (Davis 2007b: 85). Additionally, they function as a flagship to put the medium's close relationship to the spirits on public display. As public celebrations are characterised not only by spirit possession but also by food and drinks, their organisation is expensive and

8 Partly shown at the International Conference Rituals of Possession: Dissociation as Therapy in Heidelberg, 2011. 
mediums often worry about raising the economic means necessary for an upcoming celebration. In this respect, they depend on their followers or clients (hijos del altar) and the latter's willingness to support the altar. With money left at the altar by devotees as a payment for the medium's services, the medium can acquire food offerings, liquor and decoration, and hire one or even several bands of musicians. In the vodouist context, music is important, because it bestows power to stir the force. For public celebrations, specialized palo music groups are employed..$^{9}$ The musicians are positioned close to the central altar room. ${ }^{10}$ Musicians are expected to play for as many hours and with as much vigour as they are paid for with money and liquor, the latter being consumed while playing. With intensified drumbeat and the movements of the dancers, celebrations "heat up". Once the celebration is "hot", the "current is open", and summoning the spirits is not an overt procedure anymore. The force now fills the ritual space and sparks from individual to individual, and the spirits may potentially manifest in anybody who came to visit, indicating that the house hosting the celebration has become a focal point of spiritual contact. A musical ensemble that knows how to fascinate the audience, a rich buffet, liquor and distinguished decoration are factors that bring "heat" to a celebration, and lend reputation to the medium of being "active", which, again, ideally results in the acquisition of new followers and clients that seek the services of the medium. Decreasing financial support, on the other hand, may foster the impression of decreased force-as in the case of a male medium who felt the religious obligation of annually celebrating a pair of Saints. On the day the event took place, the first author could not otherwise but noticing rumours that the medium had been caught in the act of having relations with a much younger male. The atmosphere was hostile, and when the medium started to perform possession, people were not paying much attention to him. Possibly in reaction to his failure to establish the audience's engagement, his possession was characterised by breaks in character, shifting eyes, wooden movements, and nervous gesticulation. Moreover, as his altar ultimately had been poorly visited, he was not able to pay the band a decent price for their service, so the musicians mocked him by starting to play at moments when

9 However, when mediums counsel their clients for healing in a state of possession during private consultations, they are possessed without exposure to a stimulating environment (see Davis 2007b: 84f.; Schaffler 2009: 141-147).

10 A palo ensemble consists of the three palo drums or atavales, a guïra scraper, and call-response singing led by one of the instrumentalists or by a solo singer. The repertoire is fixed, although some improvisation is often applied in the lyrics and the overall sequence of tunes (for detailed descriptions, see Davis 1981 and 2007a; Piper 2012). 
the manifesting spirit wanted to speak. In the end, he had lost much credibility of truly embodying the celebrated spirit. When the event took place one year later, the number of guests was substantially reduced (Schaffler \& Brabec de Mori 2015: 109f., and unpublished data).

\section{Ceremonial behaviour and the creation of presence}

In the following section, we will present the case of a medium and healer called Ana. In particular, we are going to draw on a number of situations when she performed possession in a way exerting almost total control over the activities of those around her. ${ }^{11}$ Ana does not own a large spiritual centre to teach and baptise novices to Vodou. Thanks to her husband, who was employed in a government position before he retired, she can afford to reside in their own house in a modestly well-situated neighbourhood, and she does not financially depend on her occupation as a counsellor and healer. Maybe this, among other possible reasons, eventually led her to neglect her spiritual occupation. She ceased to work with her altar and stopped caring for her clients - "I sent people home without attending to their needs" - but soon after that started to feel bad. She suffered from a medically unexplained illness, involving nausea and dizziness. ${ }^{12}$

\section{Ana's redemption}

When Schaffler met her for the first time in 2009, Ana had just remorsefully decided to return to duty and dedicate herself to serve the spirits again, reacting to a message from Archangel Michael, her first and most important spirit. The spirit manifested "in her head" in public to tell all present that her illness was a divine punishment (castigo) for neglecting the needs of her former clients and ignoring her spiritual services. Saint Michael ordered her to reconcile with God and the spirits by undertaking a series of rituals at renowned public pilgrimage sites. The first large public ritual

11 Because of her great performance abilities, Ana was also chosen to be the protagonist of the 23-minute-movie portrait "Back to the altar - a portrait of a Dominican healer", edited by Schaffler. The film features Ana who had fallen ill with spiritual punishment (castigo) after she had refused to treat people that came to her altar in search of help. It had its premiere at the Meeting of Germanspeaking Latin Americanists in Marburg in 2011 and was also shown at the conference "Dominicanity - Perspectives on a (trans-) national concept" at the America Romana Centrum in Trier in 2014.

12 Regarding the conceptualisations of illness in Vodou see Schaffler (2009: 115-124; 2013; 2017), and Schaffler et al. (2016). 
of reconciliation ${ }^{13}$ took place at a site known as Pozo de Liborio (wellspring of Liborio), ${ }^{14}$ as foretold by the divine force. Ana ensured that no expense was spared: She rented a bus, hired a band of musicians and invited some of her former clients and several peers from the Vodou scene, including two well-known mediums, to join her. ${ }^{15}$ On the bus, the drummers were already playing and singing sacred songs together with the other passengers. When the group finally settled in the natural cave around the pilgrim's altar, Ana directed everyone, even the bus driver, to participate in the event. She fell on her knees and folded her hands to pray. By displaying deep feelings and sincerity, and by making full use of her rich, resonant voice, Ana took the lead of a religious call-response song (salve). Then she started praying to God, the Holy Spirit, and Archangel Michael to forgive her. She asked the spirits to "come back to me because I know that you haven't left me yet", to "give me back my gift (to heal)" in order to "feel like before when I was still working, and doing good deeds". Ana expected her audience to respond, and they did, repeating in chorus "perdón, perdón, perdón" or "amén" at appropriate moments. Thereafter, one of the spiritual leaders started to pray for Ana's redemption:

We have gathered here to bless those who have come here and those who could not come. You (lord) know her case and we (humans) are not in the position to judge. [...] Give her power and health, the power of Candelo Sedifé in this difficult hour because she is his daughter. With (the power of) Saint Michael as protector, I beg Monsieur Candelo and (Saint Charles) Borromeo, and the 21 divisions, to ask for forgiveness for Ana.

While the audience recited the Lord's Prayer, Ana suddenly leaned back, quickly supported by the people gathered around her. She shouted "yesses! yesses!" while dramatically bowing her voluminous body back and forth, thus signalling the onset of possession. She raised her arms towards heaven while reclining way back until her upper body rested in the arms of a man standing behind her. "Take away her glasses!", someone shouted. The members of the audience raised their arms palms upwards in order to receive the

13 The respective footage is archived under $\mathrm{V} 2902$.

14 Papá Liborio or Olivorio Mateo was a famous healer and messianic leader, born (1876) and killed (1922) near the "Pozo" in the region of San Juan de la Maguana.

15 Ana was more than pleased when one of the invited mediums introduced Schaffler to her with the intention of recording the event. To most vodouists and also to the spirits they embody it is a matter of social prestige to be filmed by a foreigner, who will surely present the footage to a large audience in some far-away country. 
force, and started to sing a gospel to thank Mother Mary. Meanwhile, the second accompanying spiritual leader rang the bell. Ana now had brought her body into an upright position and thanked the 21 divisions with a loud and decisive voice, her gaze steadily directed to the sky. The manifesting spirit was soon identified as the petró-version of Saint Charles Borromeo (Candelo Sedifé), namely as Candelo de la Frontera (or Candelo Fronté), who descended from the borderlands between the Dominican Republic and Haiti-an area known for hosting dark powers of great strength. The spirit spoke Spanish, using word endings in the way Haitian labour immigrants do. The first thing the angry spirit did was to order the bus driver not to cross his arms in front of his chest because he should also be able to receive the spiritual force, threatening him not to "fuck with" the spirit. Then, Candelo announced that his Horse was forgiven, which he underlined with three beats on her chest. Subsequently, he named the conditions that must be satisfied in order for the Horse to remain healthy, among them seven pilgrimages to seven churches, a journey to a cave, and serving food to the poor. After each demand on behalf of the spirit, members from the audience contested with fully established rapport and surprised assentation: "wow!" and "oh man".

Candelo de la Frontera now threatened his Horse: "If she does not do what I demand I will enter in a frenzy."

An audience member contested: "Ay no, old man."

Candelo: "Do you need some more proof of what I can do to my Horse? Have you seen how sick she felt during these days? How sick she was today in the morning?"

"Yes, she was sick, really sick," an audience member said.

"Sick she was!", the spirit proclaimed with a loud voice.

"She was really sick when she was lying in her room in the morning," someone approved.

"And how does she feel now?" A short pause ensued. "Relieved and liberated!", Candelo called out triumphantly.

Audience members, murmuring: "Liberation, man".

Several audience members exclaimed: "Thanks to the mercy upon us!" (gracias a la misericordia)

After the spirit had delivered his message, he saluted several members of the audience before he left. Once the possession was over, Ana went on to direct the festivities she had planned for this pilgrimage, including music and dance, the sharing of food and a cleansing ritual at the sacred wellspring, the heart of the pilgrimage site. 


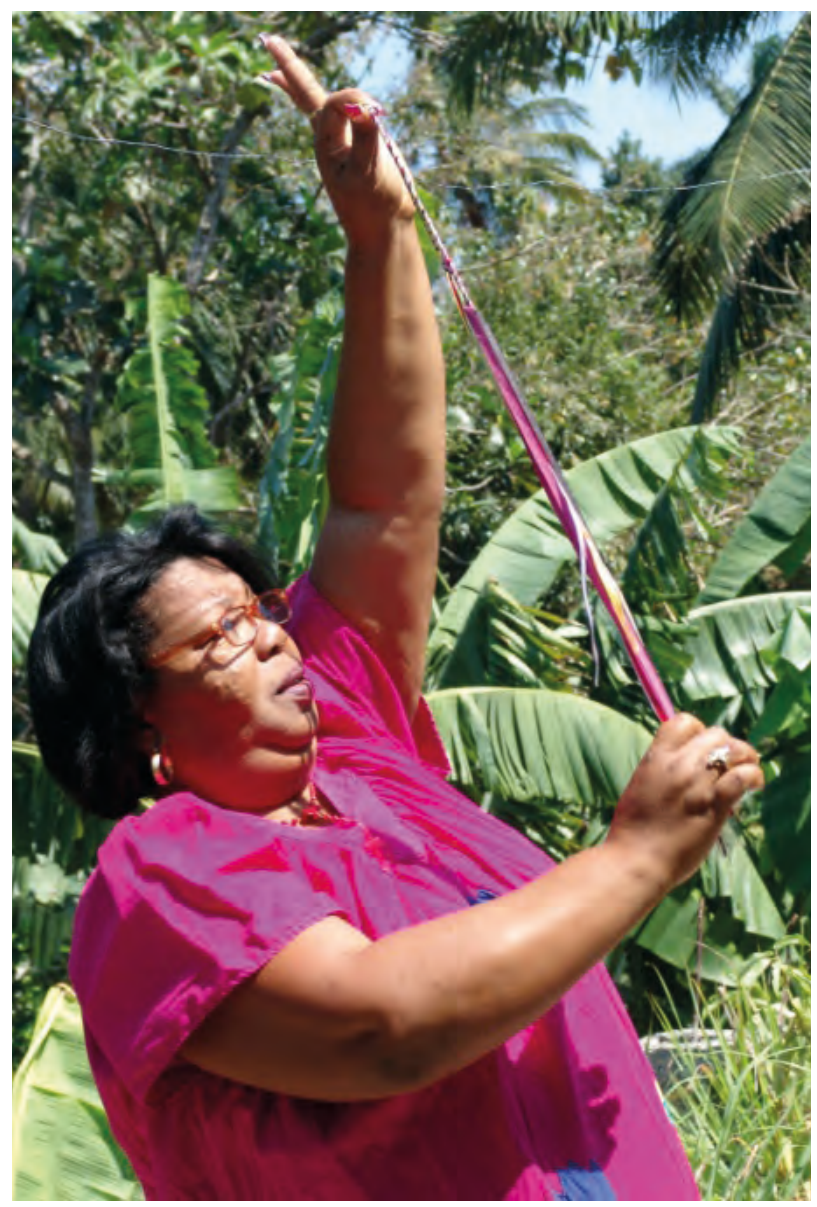

Fig. 1: Servidora using multi-coloured ribbons to represent the multitude of spirits within the 21 divisions.

Ana's reconciliation

A few months later, Ana arranged a celebration (hora santa) ${ }^{16}$ as the highlight of her cycle of redemption. ${ }^{17}$ The festivity took place at the terrace of Ana's house in front of a recently built altar dedicated to Archangel

16 A relatively quiet type of public vodouist celebration; for a detailed description of the event's origin and meaning, see Piper (2012: 203-205).

17 The respective footage is archived under $V$ 3781-3784. 
Michael. The celebration started with a lengthy session of Catholic prayer including the blessing of the food offerings, the sharing of bread dipped in wine (resembling the Holy Communion), and Ana's prayer for forgiveness in front of the main altar. She then "opened the current" by employing the jarro divisional, a mobile device consisting of a tinware pitcher. By pouring libations from the pitcher, she blessed the entrance of the building, gave reference to the musicians, and eventually saluted the different sections of her altar by ringing a small bell. During all sorts of formal activities, she was assisted by a fellow medium, who functioned as a master of ceremony (plaza). A highly renowned local ensemble of musicians engaged in singing and drumming, while a woman distributed cups filled with lemonade to the audience. The first song was slow and dedicated to the Baron of the Cemetery (barón del cementerio). While Ana threw a mix of corn, sesame, sugar, coconut and peanuts into the four cardinal directions as a symbol of prosperity, the band dedicated its tunes to Archangel Michael (San Miguel or Belié Belcan). The lyrics of the first song referred to his overwhelming power when destroying his foes, as shown in some devotional depictions (see Fig. 2). 


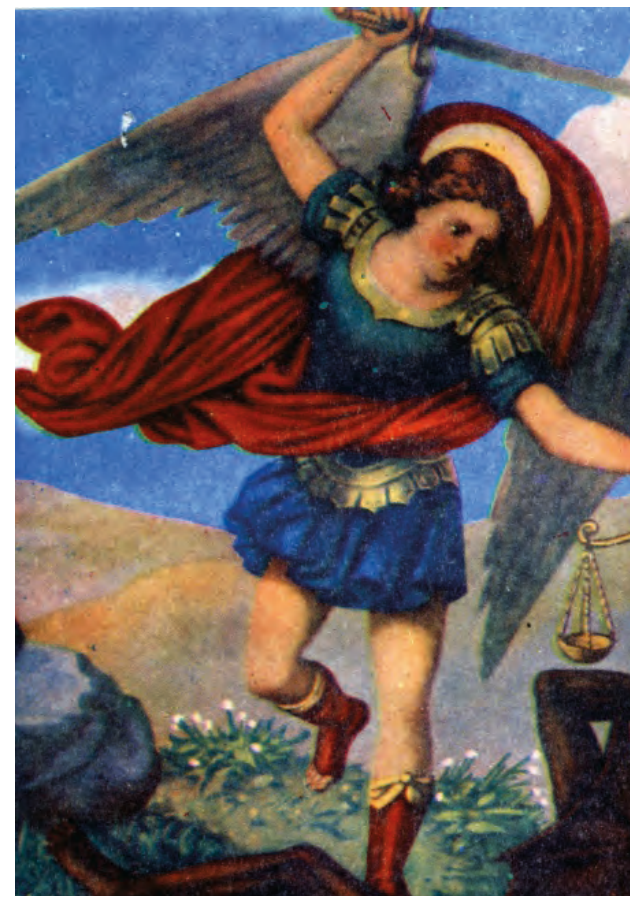

Fig. 2: San Miguel (Archangel Michael) / Belié Belcan

Belié, yo tumbo uno

Belié, yo tumbo do'

Belié, si se descuidan

Belié, yo tumbo a to'

Belié, Belié Belcan
Belié, I crush one

Belié, I crush two

Belié, if they don't watch out

Belié, I crush 'em all

Belié, Belié Belcan

More songs for the Archangel followed, one praising his nifty handling of a sword to conquer evil, another one referring to how well he protects his followers. Ana installed herself in front of the main altar, face to face with the image of Saint Michael, and started ringing the bell to summon the spirit. With her upper body rhythmically swaying, she spoke a prayer, raised her arms above her head and slowly spread them while stretching her upper body backwards. Synchronised with the rousing music, her head first moved backwards and forwards, then shook. While she turned towards the audience, a spiritual leader rushed to her assistance, ready to catch her in case she fell. He took the bell from her and proceeded with ringing, symbolically opening a pathway in front of the spirit. Ana's lips pursed, and 
her left leg was slightly lifted, thus imitating the crushing of a demon. She rolled her eyes while again shouting "yesses!", signalling the spirit's arrival. Then her arms imitated the waving of the Angel's wings. The ritual assistant lit a cigar and offered it to the spirit, then helped him to put on his green robe and to bind his turban. Unlike Candelo de la Frontera, Belié Belcan had not come to scold his Horse. The theme of his presentation was rather to announce his resurrection to the audience, and to salute, advise, bless and lay hands on every single follower. After about 30 minutes, while Belié Belcan was still occupied with his duties as a healer and consultant, the spirit of Candelo Sedifé 18 spontaneously descended upon Ana's fellow medium and current ritual assistant. Candelo Sedifé's appearance was beautiful and energetic and followed the purpose to reference the new altar and declare his satisfaction with how things went. Together with Belié Belcan, Candelo raised the central food offering (plato divisional) and distributed it among the participants.

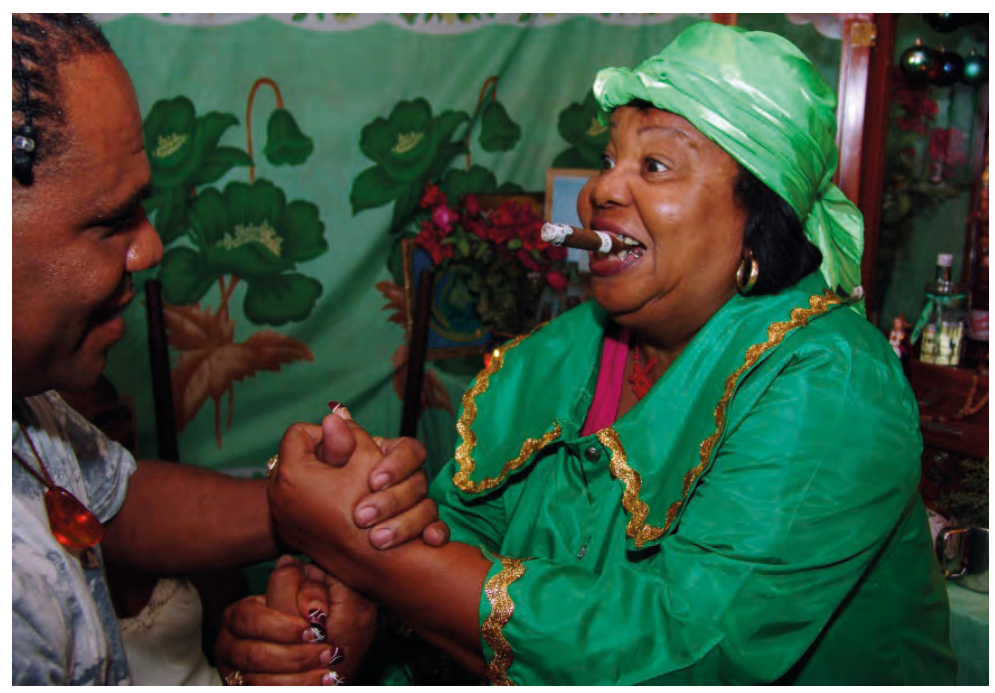

Fig. 3: The now fully manifested Archangel Michael (right) ritually salutes one of his devotees (left).

18 Candelo Sedifé is the benevolent manifestation of Candelo, in contrast to the above-mentioned petró-manifestation Candelo Fronté. 
Although Ana had already fully met her goal of reconciliation with Saint Michael, including the approval of Candelo, she entered into yet another scene of divine punishment. While her peer was still at the centre of attention acting out as Candelo, she fell from a chair and leaned her upper body against his legs. Thus she forced him to terminate his own possession episode and to instead resume his duty as a ritual assistant. Ana was now ridden by Santa Marta la Dominadora, the spirit of a dark-skinned woman carrying a snake draped over her neck. But instead of allowing her Horse to regain her footing, Santa Marta forced Ana's body to coil on the floor like a snake. On her back, she slowly crept towards the musicians, where she stopped right in front of the drums. Her eyes had turned white, and her tongue stuck out and flickered. Her fingers moved like drumsticks and her pelvis bounced up and down, but apart from these repetitive movements nothing else happened. The crowd soon gathered around her. For about half an hour, all three attending spiritual leaders did their best to release Ana from the violent force that had taken over her body. Those who were present later interpreted the event in the way that Santa Marta had issued her snake to humiliate Ana as a further punishment (castigo) for her past disobedience.

Later that night, another memorable possession occurred: a child version of Jesus Christ (Santo Niño de Atocha) descended upon Ana in order to claim his rightful place and adoration within her spirit pantheon. After noticing that no cake had been prepared for him, the child spirit dropped his head and wept. Ana's enactment of the sobbing infant had both touching and entertaining aspects, and once again, the audience fully engaged in the scene. One ritual participant hurried to a near grocery store for muffins that he offered as a substitute for the cake, but the rebellious infant shook his head and smashed the offering at the wall. The group eventually managed to feed lemonade and some remaining cupcakes to the child and promised to pass the message to Ana that she had to install his Catholic image at the altar, and, of course, to prepare a cake for him at upcoming festivities.

\section{Ana's enactment of dominance}

Another famous possession episode by Ana occurred at a public celebration organised by Rafael, the medium of a big spiritual centre. ${ }^{19}$ While Rafael, who was the owner of the celebration, was possessed by Archangel Michael, Ana dramatically invoked the same spirit. Rafael, who realised that 
he was bluntly being upstaged, quickly indicated that the spirit was about to retire from his body. After leaving Rafael's body, the force, in emic terms, immediately leapt onto Ana. Whereas Rafael's performance had not been extraordinarily convincing, Ana's was powerful. On top of this, the Archangel manifested as the fierce sword-wielding warrior and directly addressed Rafael, who is of smaller stature than Ana. The audience held their breath and the musicians remained silent. Everyone was anxious about what was going to happen. The Archangel exclaimed that "Saint Michael has a sword" and "everyone should know that I am here". To demonstrate his power, the Archangel bowed down and repeatedly hit Rafael's brow hard with his own forehead. Rafael's face contorted with pain and he had to grasp Ana's arms in order not to reel. "Thanks to the grace" (gracias a la misericordia) was the only thing for him left to say. Soon after that, Saint Michael announced on his own that he was going to leave, and Ana, exhausted, dropped into the arms of a ritual assistant. Later, Rafael could go on with another series of possession events without being disturbed again.

\section{Towards a performative analysis of possession}

The cited examples show that rituals of possession are fundamentally interactive events: a performer or a group of performers present(s) one or more enactments of possession to an audience that visits and witnesses the vodouist celebration. This audience, however, is not entirely separate from the possession performers but strongly reacts and interacts with them, sometimes to a degree of total absorption in the experience (Cardeña \& Beard 1999: 108). Following Edward Schieffelin (1996), who asked about the necessary means for the performative creation of presence, verisimilitude, and social effectiveness in Kaluli mediumistic séances, and how this was involved in the social construction of reality (ibid.: 60), we shall now approach public celebrations of Vodou and the performative articulation of possession in terms of determinative factors such as emergence, form, agenda, means, embodiment, and performance strategy (ibid.: 64). Apart from this, we will also emphazise the role of emotions, as has been suggested in more recent work discussing performative aspects of possession (Halloy 2012, 2013). In our analysis, we will draw on both the general aspects of vodouist ceremonies and the cases we presented in order to highlight some performative details.

In line with other ritual processes, vodouist celebrations are characterised by a varying degree of formality (conventionality), stereotype (rigidity), condensation (fusion), and redundancy (repetition) (Tambiah 1979: 119). In Vodou (both Haitian and Dominican), no central governing body formulates or standardises ceremonial customs (Deren 1953: 19). The way formalities 
are created and maintained varies between regions, between "schools", and even between practitioners. Most often, formal elements are present at the beginning of celebrations: when they open with prayers from the Catholic litany, followed by the chanting of liturgical church hymns. This Catholic frame stands as an opening invocation to the Holy Trinity and the Saints to bless the participants and proceedings. They are not yet directed to the misterio spirits. Likewise, certain prominent ritual actions are very formal, such as when the owner and organiser of a fiesta opens the "current" for the multitude of spirits to manifest, when she overtly invokes the celebrated spirits in front of the main altar, or when the possessing spirits eventually distribute food offerings among guests. Apart from these highlights, which follow a prescribed order, large parts of the ritual are only loosely patterned. Once the "current is open", the spirits of Vodou may take possession of their devotees spontaneously-even of uninitiated bystanders. Possession may happen simultaneously in various persons or not at all. This often depends on the music: if the band plays with little intensity or with long pauses, the audience remains distracted, chatting and drinking as if visiting an ordinary party. The experience of spiritual presence is thus generated, though only if the emerging spirits are treated with all due respect so they can honour the participants with their presence. If the performers feel that their spirit enactments are disregarded, as in the case of Rafael, who was upstaged by Ana, their embodied characters disappear. Also, our example of failed possession shows that it is very much up to the focus of the audience whether or not the messages of the spirits are heard.

In order to be successful, performance must be transformative. What is transformed during ritual, is the quality of experience or the participants' situation that comes about when performance "works". Schieffelin (1996: 64) cites the example of communitas, which is emergent in the situation only if it "happens". It is part of the work of rituals and performance to create realities like a transient personal experience of togetherness. In this vein, all participants are transformed in the process of the ritual, but no one so profoundly as the possessed person who is the centre of the ritual (Beeman 2015: 51). The most basic required emergent in a vodouist celebration is a convincing performance of spirit possession. For this to happen, "performative authority" is a fundamental condition. The ability to command authority during rituals depends on a number of factors, and some of them lie outside ritual in the everyday world (see below). At the same time, the performative authority during ritual may be so compelling that it impresses the spectators so profoundly as to influence their lives beyond the ritual. This is the case, for example, when a possessed individual functions as a healer, like Ana did, before she refused to use her "gift" of possession to 
intervene positively in the faith of others. It is "in this way that performance may become politically potent and socially creative" (Schieffelin 1996: 81).

In our example, Ana was mainly responsible for the emergence of an imaginative reality, in which several spirits came to life and expressed their desire for human attention. Except for the last scene we described, which took place at Rafael's centre, Ana served as central performer, and, supported by her peers functioning as ritual assistants, assumed the duty of a director, orchestrating both divine and human traffic and actions. Also the "plot" underlying the ritual activities was hers, presenting many important devices of drama such as reversal, discovery, pathos, suspense, and catharsis. Her actions aimed at reconciling the real world with the ideal world. The characters she represented were sharply defined through mannerism, personality, age and language use, each of them representing an aspect of mankind (see also Saint-Lot 2003: 194).

The agenda of the festivities organised by Ana supported the theme of devotion to a force majeure, which she performed through the enactment of a divine punishment. Submission to the spirits is a general and prominent motif in Vodou. As humans, when being mounted by the spirits, are supposed to retire to merely being vehicles for a higher principle, the spirit possession rite itself may be considered "basically one of submission" (Bourguignon 1979: 262f.). By means of public redemption, Ana harnessed the metaphor of the repentant sinner drawn from the religious ideology (Christianity) dominant throughout the Dominican Republic. The messages coming from the spirits may either support the official agenda of the performance ${ }^{20}$ or a more or less hidden agenda, which is informed by the performer's personal ideas, strivings, needs, and emotions. There are, however, acceptable limits as to how far the personality of an embodied mythological figure may be modified in favour of the expression of the performer's personal need (Bourguignon 1976: 46, Métraux 1955: 25). If the spectators find the personal agenda of a possessed person too obvious, they suspect that the possession is incomplete or even entirely mimicked, with the human self "filtering through" the spirit personality (Schaffler \& Brabec de Mori 2015: 113f., unpublished data). Fake possession is not acceptable,

20 Celebrations as well as specific possession performances and individual interactions of the possessed with worshippers may follow various purposes. For example, agendas in the most conventional sense are to cure an illness, to bless an individual or a house, to tell the future, to initiate a person into the cult, to make someone's business run smoothly or to enhance a person's love life, among many other possible intentions. 
as it could be abused for material benefit. ${ }^{21}$ The difficulties and pitfalls that lie in the successful performance of possession also extend to life and social relations outside of ritual. People are much more likely to mercilessly judge the authenticity of possession in cases where the performer's lifestyle is not acceptable-for example if a medium is "known" to be homosexual, a matter that more traditional minded members of the community consider "immoral". In this respect, Ana's possession performance is relatively free of risk. She lives a wealthy life together with her husband without any major problems, which is usually interpreted as God's reward for righteousness. Nobody will suspect a hidden agenda in terms of rip-off, as she clearly does not depend on the financial yield of her altar to survive. On top of this, repenting her sins (not serving the spirits and ignoring the needs of her clients) has become the "official agenda" of her pilgrimages and celebrations.

For the performer to create or evoke an imaginative reality beyond the activities of everyday life, a certain knowledge as well as charisma and "expressive competence" (Baumann 1986) are required. Halloy (2013), referring to the mechanism of "putting in presence" the divine, noted that gestural iconicity primarily contributes to the identification of the spirits during the possession episodes. In her invocation of the Archangel Michael, Ana not only took in the typical facial expression and posture of the spirit involving twisting her mouth and raising one leg, but felt confident enough to add a further, untypical, detail, namely a movement of her arms, symbolising the Archangel's wings, thereby also "individualising" the performance (ibid.: 35). Apart from this, the embodied iconic features resonated with the mythological content of the songs in honour of the spirit. Such perfect matching between mythological content expressed in songs and performance, however, hardly occurs. In our example, it might have manifested due to Ana's particularly careful orchestration of the event.

The most subtle performance strategies applied lie in strategically modulating the quality of interaction with the audience (Schieffelin 1996: 66). In order to maintain the focus of attention, Ana perceived the mood and energy of the audience, and modulated it with appropriate actions like raising her voice or remaining silent, and by addressing a wide range of meanings and emotions. By embodying authoritarian characters like the sword-wielding Archangel Michael or the dangerous petró-spirit Candelo de

21 A fake medium's client could be persuaded to purchase unnecessary and costly services, or be seduced with the excuse of a false spiritual relationship (demands of spirits towards their devotees sometimes include a request for marriage). A pretending medium may try to deceive a devotee to offer a valuable gift or to allow an erotic adventure right in front of the altar (unpublished data). For the discussion of fake possession regarding the Brazilian Tambor de Mina cult, see Halperin (1995). 
la Frontera, she represented her ability to deal with great (and even dark) spiritual force. Her manifestation of a fragile child spirit, on the other hand, showed her capacity to attract sweet and innocent forces, too.

During public vodouist celebrations, the moments when spirits manifest are of particular strategic importance. The "centrepiece possession" that occurs during public celebrations when the room is already crowded and just about to be "heated" strategically exploits a maximum of attention (Schaffler \& Brabec de Mori 2015: 109). When Ana manifested Archangel Michael as "centrepiece" during her hora santa, she did so after a lengthy phase of less interesting events like praying and blessing the offerings. However, central performers face the challenge that at the same time the celebration should not remain a one-man show. A number of possessions are expected in order to demonstrate that the "current is open" and the celebration is "hot". Therefore, they depend on the support of invited or visiting mediums who invoke further spirits. This eventually becomes contagious, causing other participants to follow. However, the co-participation of other mediums bears a certain risk for being upstaged, as in the case when Ana invoked Archangel Michael while the spirit was still possessing her peer Rafael. Ana used her possession to demonstrate her ritual authority, and Rafael had no other choice than putting a good face on the matter.

Although the singing and drumming is often seen as either peripheral or just as a part of stimuli for creating an overflow of perception used to trigger and socialise trance states (based mainly on the seminal book by Gilbert Rouget, 1985), it is of vital importance to the festivity. Intensification of stimuli is recognised as a crucial aspect of "heating up", thereby creating the ecstatic mood in which the ceremony evolves. As our example of failed possession has shown, it is very important that the musicians are in tune with the owner of the fiesta, which is most easily secured by inviting a renowned group of palo musicians and paying them as well as possible. The leader of the band must keep an eye and an ear on what happens at the altar and the rest of the room in order to quickly react to any hint about spirit activity. If the band pays attention, it can quickly switch tunes or adapt the lyrics for the situation, for example if a spirit appears, manifests, or engages in salutations or other interaction. As was already noted by Rouget, the music often cedes when possession is complete. This can be observed precisely in Dominican Vodou. The music provides the "heat" for the spirit to enter the body of the Horse, but at the moment the spirit is manifest 
and recognised as such, the music suddenly stops. ${ }^{22}$ The hush that falls at such a moment allows participants to clearly hear and understand the first phrases spoken by the manifest spirit, often stereotyped exclamations like "Gracias a la misericordia!" After this moment, participants often start to speak loudly, commenting on who is this spirit, how to react, which paraphernalia and offerings have to be given to the spirit, and so on. When this is all done and the spirit turns towards salutations and private consultations of devotees, the band starts playing again, performing songs that reference the present spirit or that induce the end of possession trance.

As individual practitioners shape their spirit roles rather from knowledge and memories that were accumulated by visiting congregations of the cult (Métraux 1955: 24f.) than from formal tuition (Davis 2007b: 79), possession behaviour is largely acquired through observation and practical learning. Our videographic observations (beyond Ana's case) suggest a direct proportionality of acquired experience with tendencies to stereotyped and theatrical qualities in spirit performance. We assume that a practitioner's mental representation of a spirit sharpens with experience, allowing for an increasingly accurate realisation of the spirit role. Moreover, mediumistic development, particularly at the beginning of the process, draws extensively upon bodily experience (Pierini 2016a). Altered states of consciousness (trance, dissociation) underlying possession are characterised by intensive movement, vocalisation, bodily expressions, and changes in somatic sensations and body image, and they are more likely to happen if ritual participants are exposed to a specifically stimulating environment-where drumming, dancing, and singing facilitate an atmosphere of intense spiritual presence by crowd-contagion (e.g. Bourguignon 1976, 2004; Cardeña 1989; Cardeña et al. 2009; Halloy 2013). Seligman, for the case of Brazilian Candomblé, suggested that individuals who experience possession trance have a particular propensity for deep internalisation and a tendency to form intense body memories (Seligman 2005, 2014). To these individuals, the patterned actions and sensual stimuli of ceremonies provide powerful material to be embodied. In a typical vodouist celebration, incense is burnt, and perfumes are applied on sensible areas such as the back of the neck and the forehead of a person who is about to enter trance. Within the sonic domain, constant drumming transmits shifting patterns, and a small bell is rung with the aim to summon spirits. People move rhythmically in crowded rooms,

22 Also in Haitian Vodou, effective summoning of spirits does not depend so much on the correct lyrics sung at a certain point in time but rather on the degree of involvement and enthusiasm of both musicians and surrounding people that heats up a ceremony. The "heat" itself attracts the spirits (see Lowenthal 1978: 403). 
sometimes waving pañuelos (kerchiefs that serve as spiritual bases) in front of them, thereby sending the spiritual force into the directions indicated by their movements. They avoid crossing their arms or legs, and shoes, tight wardrobe, hairbands, glasses and anything else that is considered to restrict the flow of force are loosened or removed (Schaffler 2017; Schaffler \& Brabec de Mori 2015, unpublished data). According to Seligman (2005, 2014), these ritual stimuli effectively entrain the physiological systems of ritual participants. The ritual context allows them to respond freely and embrace the feelings of intense physical and emotional activation. This way, religious principles are not only transmitted through observation and repetitive practical execution of rituals but also through the mediums' repeated bodily experience (Halloy 2012; Pierini 2016a). Ana reported that when spiritual force would manifest or "rise" in her body, she would not only feel shivers and goose pimples, but a specific feeling of energy would enter her body through the feet, causing sensations in the stomach area before it would go up to the head, causing dizziness, followed by a "loss of consciousness" at the time when the spirit identity fully replaced her own. She experienced spiritual presence very intensely and enacted it the same way, with expressions ranging from deep anger to tearful grief. Through the experience of strong feelings she was able to provoke empathic reactions in her audience, thereby blurring the demarcation between performer and audience (see also Halloy 2013: 42f.). In this vein, Schechner, referring to Grotowski's "Living Theatre", concluded that only when there is no distinction between the performer and the audience, the move from theatre to ritual happens (cited after Saint-Lot 2003: 77; see also Cardeña \& Beard 1999: 107f.). Although we identified Ana as the central performer of her festivities, also the musicians and other participants bore responsibility for creating a sense of spiritual presence. This cooperative action is necessary for a properly passionate execution of "bringing heat" to a ceremony, thus attracting a multitude of spirits. Only if participants passionately sing along with the musicians and engage in dancing with excitement, a concentration of energy and mutual resonance emerges, "dissolved into the performance as participants". The audience's fascination with Ana's passionate affection was particularly evident when Ana embodied the resentful spirit Candelo de la Frontera who imposed several obligations on her, culminating in the threat of making her sick again. As a reaction to his furious authoritarian rule, participants signalled their utter disposition of obeying, always ready to affirm, sing, or to keep silent at his command. Likewise, when Ana embodied the spirit of the Infant Christ, the audience reacted to her tearful sobbing with great empathic resonance, allowing her virtually absolute control of the situation. 


\section{Conclusion}

In this article, we referred to the performance of spirit possession, i.e. to episodes wherein individuals enter trance states and feel that they are possessed by spirits that use them as "Horses", and "own their heads". Public celebrations of Vodou are based on drumming, singing, dancing and the handling of food and liquor as service for the spirits. From the local perspective, the aim of these activities is to attract and manage spiritual force, so that specific spirits may take possession of and communicate through their human Horses. The authoritarian air that Ana and her successful peers emanate during possession episodes thus results from a number of factors that are directly or indirectly linked to ritual performance. Among the indirect links are:

- The socio-economic status: disposing of sufficient resources guarantees that, first, the owner of a festivity can buy items and pay people, both crucial for "heating up" a celebration; and second, that it is less likely that peers suspect hidden agendas related to monetary benefit.

- Lifestyle: a Horse that shows a more or less immaculate lifestyle (Ana is neither "accused" of homosexuality nor immoral behaviour as she lives a "Catholic" marriage; she was never caught stealing or betraying, and was never accused of witchcraft or "black magic" within the community) is much harder to criticise in the framework of Catholic morale given in Dominican Vodou.

- Networking: by raising one's own reputation and maintaining friendly relations with neighbouring mediums, the Horse can count on the latter's help in providing the group-contagion that functions like a "booster of heat" in a celebration.

If these factors are given and well worked out, the Horse's performance is much more likely to succeed and to appear convincing. Peers and clients will more easily be impressed and react positively. However, the above-mentioned background has still to be condensed within the ritual and translated into performance. During the celebration, a number of further factors apply, all of them building upon, or relating to, said background. Those most relevant for the construction of authority are:

- Emergence and group-contagion: with the orchestration and conduct of the scenery, an air of "heat" that results in an accumulation 
of "spiritual force" has to be achieved. Therefore it is crucial that the owner of the celebration maintains contact and gives feedback to all involved: peer vodouists, audience and clients, musicians, and the spirits (and their representations like images on the altar).

- Emotion: a possession that is embodied in perfect style but not emotionally touching the people present will never be as impressive as an episode that imbues the scenery with emotional attachment, as in the given examples. If the performer opens his or her personality and displays deep emotional immersion into the spirit character, it is likely that those present respond with emotional attachment, too, adding to the effect of group-contagion.

- Form: The vodouist has to maintain the balance of displaying his or her own emotional agenda and immersion, and at the same time the typical attributes of the possessing spirit during the correct phase of the celebration and in tune with the music and the imagery displayed at the altar and in the room. Only if the possession episode correlates with at least some minimum standardised forms will it be recognised as valid and authoritative.

Based on this analysis, we suggest that the quality of possession and how the audience judges it is largely constructed through factors outside the ritual framework. With economic and moral assurance and self-confidence, and standing in good terms with peers, a vodouist still has to organise appropriate musicians, display a properly maintained altar and correlate the celebration well with an agenda that is considered relevant and important to the participants. Only on top of that, the performance by itself, requiring the skilful orchestration and execution of emergence, embodiment, emotion, and form (Espírito Santo 2012, 2015; Halloy 2013; Pierini 2016a; Schieffelin 1996), can condense all these factors into an authoritative manifestation of a spirit in the human world, thus drawing the audience into the interactional creation of a performance reality. 


\section{References}

Baumann, R. 1986. Story, Performance, and Event. Cambridge: Cambridge University Press.

Beeman, W.O. 2015. "Religion and Ritual Performance". In: Pradier, J.-M. (ed.). La croyance et le corps. Esthétique, corporéité des croyances et identités. Bordeaux: Presses Universitaires de Bordeaux, 35-58.

Bourguignon, E. 1976. Possession. San Francisco: Chandler and Sharp.

Bourguignon, E. 1979. Psychological Anthropology. New York: Holt, Rinehart and Winston.

Bourguignon, E. 2004. "Possession and Trance". In: Ember, C.R. \& M. (eds.). Encyclopedia of Medical Anthropology: Health and IIlness in the World's Cultures Topics. Vol. 2. New York: Kluwer Academic/ Plenum Publishers, 137-145.

Brabec de Mori, B. \& A. Seeger. 2013. "Introduction: Considering Music, Humans, and Non-humans". Ethnomusicology Forum 22 (3): 269-286. [Special issue (B. Brabec de Mori, ed.): The Human and Nonhuman in Lowland South American Indigenous Music]

Brabec de Mori, B. (in print). "How to Charge a Voice with Power? - Ritual Singing in the Western Amazon". In: Pillen, A. \& E. Amy de la Bretèque (eds.). Tones of Others. Philadelphia: University of Pennsylvania Press.

Cardeña, E. 1989. "Varieties of Possession Experience". Association for the Anthropological Study of Consciousness Quarterly 5 (2-3): 1-17.

Cardeña, E. \& J. Beard. 1999. “Artificios verídicos: Chamanismo, actuación y realidad”. Cuaderno de Teatro 58 (1): 99-112.

Cardeña, E. et al. 2009. "Possession/Trance Phenomena”. In: Dell, P.F. \& J.A. O’Neil (eds.). Dissociation and the Dissociative Disorders: DSM-V and Beyond. New York: Routledge, 171-181.

Davis, M.E. 1981. Voces del purgatorio: Estudio de la salve dominicana. Santo Domingo: Museo del Hombre.

Davis, M.E. 1987. La otra ciencia: El Vodu Dominicano como religion y medicina popular. Santo Domingo: Editora Universitaria - UASD.

Davis, M. E. 2007a. "Oral Musical Traditions of the Dominican Republic". In: Kuss, Malena (ed.). Music in Latin America and the Caribbean: An Encyclopedic History. Volume 2: Performing the Caribbean Experience. Austin: University of Texas Press, 189-215.

Davis, M.E. 2007b. "Vodú of the Dominican Republic: Devotion to ,La Veintiuna División“". Afro-Hispanic Review 26 (1): 75-90.

Deive, C.E. 1996. Vodu y Magia en Santo Domingo. (Fundación Cultural Dominicana). Santo Domingo: Taller.

Deren, M. 1953. Divine Horsemen. The living Gods of Haiti. London: Thames and Hudson.

Desmangles, L. 1992. The Faces of the Gods: Vodou and Roman Catholicism in Haiti. Chapel Hill: University of North Carolina Press.

Espírito Santo, D. 2012. "Imagination, Sensation and the Education of Attention Among Cuban Spirit Mediums". Ethnos 77 (2): 252-271.

Espírito Santo, D. 2015. Developing the dead. Mediumship and Selfhood in Cuban Espiritismo. Gainesville: University Press of Florida.

Goffman, E. 2003 [1959]. Wir alle spielen Theater. Die Selbstdarstellung im Alltag. München: Piper.

Halloy, A. 2012. "Gods in the Flesh: Learning Emotions in the Xangô Possession Cult (Brazil)". Ethnos 77 (2): 177-202. 
Halloy, A. 2013. "Percibir la presencia de los dioses. La danza de posesión en un culto afro-brasileno". Revista Latinoamericana de Estudios Sobre Cuerpos, Emociones Y Sociedad 4 (10): 30-47.

Halloy, A. \& V. Naumescu. 2012. "Learning Spirit Possession: An Introduction". Ethnos 77: 155-176.

Halperin, D. 1995. "Memory and ,Consciousness' in an Evolving Brazilian Possession Religion". Anthropology of Consciousness 6 (4): 1-17. [Online: <http://doi.org/10.1525/ac.1995.6.4.1>]

Jewitt, C. 2012. "An Introduction to Using Video for Research". National Centre for Research Methods Working Paper 03/12: 1-22. [Online: <http://eprints.ncrm.ac.uk/2259/>]

Knoblauch, Hubert et al. (eds.). 2006. Video Analysis: Methodology and Methods. Qualitative Audiovisual Data Analysis in Sociology. Frankfurt am Main: Lang.

Landies, M.E. 2009. "The Band Carries Medicine: Music, Healing and Community in Haitian/Dominican Rara/Gaga". PhD dissertation, Graduate School of Arts and Sciences. New York: Columbia University.

Lowenthal, I. 1978. "Ritual Performance and Religious Experience: a Service for the Gods in Southern Haiti". Journal of Anthropological Research 34 (3): 392-414.

Métraux, A. 1955. "Dramatic Elements in Ritual Possession”. Diogenes 3: 18-36.

Métraux, A. 1998. Voodoo in Haiti. Gifkendorf: Merlin.

Pierini, E. 2016a. "Becoming a Spirit Medium: Initiatory Learning and the Self in the Vale do Amanhecer". Ethnos 81 (2): 290-314.

Pierini, E. 2016b (in print). "Embodied Encounters: Ethnographic Knowledge, Emotion and Senses in the Vale do Amanhecer's Spirit Mediumship". Journal for the Study of Religious Experience.

Piper, D.C. 2012. "Urbanization, Gender, and Cultural Emergence in the Music of Dominican Popular Religion: Palos and Salves in San Cristóbal”. PhD thesis. Providence, RI: Brown University.

Rouget, G. 1985. Music and Trance: A Theory of the Relations Between Music and Possession. Chicago \& London: Chicago University Press.

Saint-Lot, M.J.A. 2003. Vodou: A Sacred Theatre - The African Heritage in Haiti. Coconut Creek: Educa Vision.

Sax, W. \& J. Weinhold. 2010. "Rituals of Possession". In: Brosius, C. \& U. Hüsken (eds.). Ritual Matters. Dynamic dimensions in practice. Delhi: Routledge, 234-250.

Schaffler, Y. 2009. Vodú? Das ist Sache der anderen! Kreolische Medizin, Spiritualität und Identität im Südwesten der Dominikanischen Republik. (Wiener ethnomedizinische Reihe, 7). Wien \& Zürich: LIT-Verlag.

Schaffler, Y. 2013. “El caballo que se volvió lobo. Análisis del fenómeno de ,posesión espontánea“". In: Sigl, E., Y. Schaffler \& R. Ávila (eds.). Etnografías de América Latina. Ocho Ensayos. Guadalajara: Universidad de Guadalajara, 133-164.

Schaffler, Y. 2017. "Spirit Possession in the Dominican Republic: From Expression of Distress to Cultural Expertise". In: Felbeck, C. \& K. Andre (eds.). Dominicanidad / Dominicanity. Perspectivas de un concepto (trans-)nacional / Perspectives on a (trans-)national concept. Frankfurt am Main: Peter Lang, 221-237.

Schaffler, Y. \& B. Brabec de Mori. 2015. "A multi-perspective analysis of videographic data on the performance of spirit possession in Dominican Vodou". International Forum on Audio-Visual Research - Jahrbuch des Phonogrammarchivs 6: 100-125.

Schaffler, Y. et al. 2016. "Traumatic Experience and Somatoform Dissociation Among Spirit Possession Practitioners in the Dominican Republic". Culture, Medicine and Psychiatry 40 (1): 74-99. [Online: <http://doi.org/10.1007/s11013-015-9472-5>]

Schieffelin, E. 1996. "On Failure of Performance. Throwing the Medium out of Séance". In: Laderman, C. \& M. Roseman (eds.). The Performance of Healing. London \& New York: Routledge, 59-89. 
Schieffelin, E. 1997. "Problematizing Performance”. In: Hughes-Freeland, F. (ed.). Ritual, Performance, Media. New York: Routledge, 194-207.

Seligman, R. 2005. "Distress, Dissociation, and Embodied Experience: Reconsidering the Pathways to Mediumship and Mental Health". Ethos 33 (1): 71-99.

Seligman, R. 2010. "The Unmaking and Making of Self: Embodied Suffering and Mind-Body Healing in Brazilian Candomblé". Journal of the Society for Psychological Anthropology 38 (3): 297-320.

Seligman, R. 2014. Possessing Spirits and Healing Selves. New York: Palgrave McMillan.

Tambiah, S. 1979. A Performative Approach to Ritual. London: Oxford University Press.

Yvonne SCHAFFLER:

Center for Public Health, Medical University of Vienna

http://yvonne-schaffler.eu

yvonne.schaffler@meduniwien.ac.at

Bernd BRABEC DE MORI:

Institute of Ethnomusicology, University of Music and Performing Arts Graz http://ethnomusikologie.kug.ac.at/en/institute-13-ethnomusicology.html http://wiki.cibera.de/index.php/Brabec_de_Mori,_Mag._Dr._phil._Bernd bernd.brabec@kug.ac.at

doi: 10.1553/jpa7s138-166 